\title{
The Impact of Authentic Listening Materials on Elementary EFL Learners' Listening Skills
}

\author{
Masoud Khalili Sabet \\ Faculty member at the University of Guilan \\ Tel: 00989113313992_E-mail: sabetma2002@yahoo.com \\ Hamed Mahsefat (Corresponding author) \\ MA student at TEFL at the University of Guilan \\ Tel: 00989117577131 E-mail: Hamed.mahsefat@gmail.com
}

Received: 29-06- 2012

doi:10.7575/ijalel.v.1n.4p.216
Accepted: 08-08- 2012

Published: 01-09- 2012

\begin{abstract}
Listening is one of the most pivotal skills, though; it is unjustly neglected throughout the literature. It was previously considered as passive skill but now those myths have been demystified. Therefore seeking the innovative trends for teaching and developing listening for EFL students are taken for granted. Lack of adequate exposure to listening and dearth of attention with regard to these issues sets the ground for authentic listening materials to fill the cited gaps in Iranian context. There have been controversial ideas based on studies in dealing with authentic listening materials. Their results ranged from totally abstinence to completely utilizing. This study intends to investigate the impact of authentic listening materials on listening skills of Elementary students at university level. To this aim, sixty students of university were randomly assigned to two groups. One group was exposed to and received authentic listening materials (experimental group) and the other groups received simplified listening materials (control group). A proficiency test (consisted of two sub-tests; listening comprehension and listening perception) was used as a pretest to measure the students' potential differences at outset of study. After the instruction sessions the same proficiency test was administered for both groups. Besides students feedback survey was given to experimental group to evaluate their attitudes and opinions regarding the materials. Analysis of quantitative study and comparing the mean scores of two groups via t-test showed that students who were exposed to authentic materials performed better in posttest. The analysis of feedback survey also denoted their satisfaction and positive attitudes to authentic listening materials.
\end{abstract}

Keywords: Listening Skills, Authentic Listening Materials, EFL, Elementary

\section{Introduction}

Listening is one of the four language learning skills, targeted variously by experts. Oxford Dictionary defines it as" make an effort to hear something: listen to the radio; listening for the bell. To pay attention; heed". (Lynch (1997, cited in Schmitt, 2002) puts: "listening involves making sense of spoken language, normally accompanied by other sounds and visual input, with help of our relevant prior knowledge and the context in which we are listening". As it is clear from the above-mentioned quotation, it is not a one-layered phenomenon, but an amalgamation of bundles of related process in which remained unnoticed for first language acquisition due to its natural and effortless nature. Krashen (1987) states in his input hypothesis, that the role of listening for acquisition is undeniable. However, unlike its importance role, it is a so-called "Cinderella skill" (Nunan, 1997, p.47) in EFL situation, receiving only slight emphasis in instruction. Traditionally listening was considered as a "passive process, in which our ears were receivers into which information was poured..." (Schmitt2002:193). Having been demystified those unjustly-neglected simplistic views, (myths) nowadays; it is regarded, as Schmitt (2002) aptly argued, a ..." active, interpretive process". It is often assumed that listening could be acquired through exposure rather than teaching. That's why; maneuvering on this domain is really a worth-while process in applied linguistics and in related disciplines in new millennium. Ever since the advent of communicative approaches in teaching, lots of efforts have been made by material developers and educational policy makers to 
make learning materials (tasks) as real-life like as possible. However there is significant difference in opinions regarding the presence of authentic materials in the FL classroom. Views range from strong caution, if not stop, to encouragement. The term authentic material has been defined in different ways throughout the literature. Scholars argue for the motivating power of authentic materials. Listening skill, better to say, listening skills as a mother skill "comprise a large number of sub-skills, whose value and relevance vary from one situation to another" (Lynch, (1995).Mendelson, (1995).as cited in Schmitt, 2002.p, 198). He came up with 33 micro-skills for conversational listening and 18 for academic listening. Based on "taxonomies" which he labeled, for all of language stakeholders (i.e. teachers, learners, etc.) they should be distinguished and prioritized. In a similar study, Rost (1990) posited the "cluster" of listening sub-skills. His clusters such as "enabling skills (includes perception, interpretation...) and enacting skills" are of this type which had been taken into account by Anderson (1985) as "Perception, Parsing and Utilization". For this paper, just two components of listening skills, perception and comprehension have been targeted.

\subsection{Statement of the problem}

Studies have demonstrated that adults spend nearly half of their communication time on listening (Gilman \& Moody 1984, cited in Vandergrift, 1999), but according to many (Nunan, 1999, Oxford, 1993, Schmitt, 2002, Vandergrift, 1999) it has not been dealt with as it was supposed to be. Since the role of listening skills in language learning was taken for granted, it merited little research and pedagogical attention. Listening skills, despite its prominent roles it plays in language learning, have been ignored in language learning. In EFL situation it has been viewing as a great issue which lots of students are bereft of an acceptable level of comprehension in a par with other skills. Having unique characteristics such as, being ephemeral, enjoying non-written language feature, redundancy, etc., made listening by nature different from other skills. From one hand half of their communication time on listening. It plays a significant role in daily communication and educational process. In spite of its importance, the development of listening ability has received only slight emphasis in language instruction. On the other hand, there are many limitations and restrictions in getting access to materials. Most notably the lack of 'exposure' to real life situation for 'natural' development of language, as argued by Krashen (1987) is a big problem for ESL and EFL students. It is therefore important for EFL programs to prepare students for successful listening in EFL contexts by implementing authentic listening materials in the EFL classes. Iranian students live in an EFL environment, lacking the opportunities to acquire through exposure.

\subsection{Significance of study}

Listening is the most frequently used form of language skill (Thanajaro, Metinee; Shrum, Judith,_2000), which plays a significant role in daily communication and educational process. According to what has been stated by Krashen(1987) in input hypothesis, listening materials plays a great role in "natural" development and moving from one step to the others, to learn effortlessly, he argues that, learners should be in a acquisition-rich environment and be in natural exposure to language. Acquiring listening skills can even be frustrating for some students. Researchers then began to recognize the importance of listening and its role in comprehensible input (Krashen, 1982), and attention to and adoption of newer comprehension-based methodologies brought the issue to the fore. Listening became a skill to be reckoned with and its key position in communication recognized (Feyten, 1991; Hadley, 2001). Given the importance of listening in language learning and teaching it is essential to give our learners opportunity to develop and improve their listening skills not only in the classroom, but outside the classroom as well. Nunan (1999) makes the point that learners should be fed as rich a diet of authentic data as possible, because, ultimately, if they only encounter contrived dialogues and listening texts, their learning task would be made more difficult. He also goes on to say that it is important that learners listen to and read authentic material of as many different kinds as possible. This will help and motivate the students by bringing the content and the subject matter to life for them, and enable them make the important connections between the classroom world and the world beyond (Philips \& Shettlesworth 1978; Clarke 1989; Peacock 1997, cited in Richards, 2001). Embarking upon the authentic listening materials provide a broad view to listening by giving an extra capacity to teachers, students, schools and educational policy makers to deal with listening effectively and effortlessly. Authentic materials bring reality into the class and have various advantages, e .g motivation, cultural awareness, giving real exposure, creative teaching. (Phillips \& Shettlesworth 1978;Clarke1989; Peacock 1997 cited in J. C. Richards(2001) Also because of the lack of inexpensive and easily-accessible materials, they can provide easily-accessible and ready-made materials for users due to the ubiquities advent of multimedia. finding rich-designed textbooks or materials is difficult if not very difficult. So this quotation might be relevant to whisper that "use no materials, published or unpublished, actually conceived 
or designed as materials for language teaching."(Allwright, 1981 p.173) These materials also cover wide ranges of "ideal sources of materials for extensive listening (Harmer, 2007, p.303). That is why the more we pay attention to authentic materials, the better and easily we will find listening in the Macro strategies of post method states that "promoting learner autonomy". (Kumaravadivelu, 2006 p.206) is a principle, so again authentic material can bring autonomy in learning.

\subsection{The review of literature}

There is a slight difference in the definition of authentic materials in literature. However, there is a common point in these definitions which is 'exposure to real language and its use in its own community' (Kilickaya, 2004). Goals, objectives, learner needs and interest and 'natural' are 'appropriate' and 'quality' factors that are taken into consideration in Rogers (1988) definition when it comes to real life and meaningful communication (p. 467). Harmer (1991), cited in Matsuta defines authentic texts as materials are designed for the speakers of the language students. Jordan (1997, p. 113) highlights that to authentic texts are not written for the aim of language teaching. According to Peacock (1997) the definition of authentic materials is the materials that have been produced to fulfil some social purposes in the language community. Martinez (2002) defined that "Authentic would be material designed for native speakers of English used in the classroom in a way similar to the one it was designed for" (p.1). Widdowson (1987) puts "Authenticity...is a term which creates confusion because of a basic ambiguity" (p.30). Little et al. (1988, as cited in Guariento \& Morley, 2001) define authentic material as "an authentic text...created to fulfill some social purpose in the language community in which it was produced" (p.347). Bacon \& Finnemann (1990) define authentic materials as texts "produced by and for native speakers of the target language" (p.469). According to Schulz (1991), the use of authentic materials in the FL classroom is rigorously supported by Krashen's 'affective filter' hypothesis for SLA as well, in which deals with the way in which affective and attitudinal factors such as motivation, self-confidence and anxiety alter learners' receptivity to the target language.

Krashen(1987,cited by Larsen-Freeman \& Long, 1991) believes that a high affective filter inhibits acquisition, whereas a low affective filter promotes it. In this regard, Krashen (1989) identifies materials which tend to lower the affective filter as "comprehensible input on topics of real interest" (p.29), that is, by and large, a hint if not direction, to authentic materials.

Besides, Mishan (2005) claims that the focal pedagogical rationale for using authentic materials in FL teaching originates from what is called 'the $3 \mathrm{C}$ 's', that is to say, culture, currency, and challenge. He explicates that:

"Culture, in that authentic texts incorporate and represent the culture/s of speakers of the target language; currency, in that authentic texts offer topics and language in current use, as well as those relevant to the learners; challenge, in that authentic texts are intrinsically more challenging yet can be used at all proficiency levels" (p.44).

\subsubsection{The role of authentic materials in FL teaching and learning}

There is growing body of research on the role authentic materials on FL teaching. Researchers and teachers increasingly acknowledged the need for and usefulness of authentic materials in the field of language teaching. Empirical studies have substantiated the positive results taken by learners who have opportunities to interact with and deal with authentic texts. Studies, such as Miller (2005) and Thanajaro (2000), revealed that incorporating authentic materials lead to aural language development. In addition, Otte (2006 cited in Al-Musallam, 2009) investigated the impact of aural authentic texts on listening comprehension abilities of four adult ESL students at an American university. He concluded that exposure to authentic materials would lead to improving students' listening comprehension abilities and motivation. By the same token, , conducting on intermediate-level students, Herron \& Seay (1991)found that those students who listened to authentic radio tapes as a substitute for regular classroom activities demonstrated significantly greater listening comprehension than those students for whom the authentic radio program was not a part of the semester's curriculum. Their research confirmed that, the more exposure to authentic speech the more improve in listening-comprehension skill. Comparing the impact of authentic versus textbook materials on developing learners' communicative competence, Gilmore (forthcoming, as cited in Gilmore, 2007) investigated the impact of authentic versus textbook materials on developing learners' communicative competence in a one-year quasi-experimental study at a Japanese university. He found that those who received the authentic input, made statistically significant improvements over those who received textbook input on six out of eight tests designed to measure different types of competence. He found, "This result was attributed to the fact that the authentic input allowed learners to 
focus on a wider range of features than is normally possible ... and that this noticing had beneficial effects on learners' development of communicative competence" (p.111).

In this regard, Weyers (1999) examined the impact of exposure to authentic video on the language acquisition process of university students of Spanish. The results indicated that those students who were exposed to authentic video a showed a significant improvement in listening comprehension skills and some component parts of the communicative competence.

Hadley (2001) concludes that the, "use of real or simulated travel documents, hotel registration forms, biographical data sheets, train and plane schedules, authentic restaurant menus, labels, signs, newspapers, and magazines will acquaint students more directly with real language than will any set of contrived classroom materials used alone" (p.97). Thus, it seems sensible to base students' reading practice on a variety of authentic texts.

Moreover, Morton (1999) asserts that developing strategies in comprehending authentic texts can help students to develop writing proficiency in the target language. He explicates, "Students ... need to learn the register that is appropriate for their own essays. For this, there is no substitute for authentic academic texts .... which can develop students' ability to master basic rhetorical devices" (p. 182). In this regard, Carter and Nunan (2001) assert that the use of authentic materials raises learners' awareness of not only grammatical and lexical but also stylistic features. Moreover, professionals in favor of authentic materials assert that exposure to authentic materials should introduce to the learners in the earliest stages of language learning (Bacon, 1989; McNeil, 1994; Miller, 2005), claiming that an early exposure to such texts will aid students to develop useful strategies for more complex tasks later on. Herron \& Seay (1991) state that, using authentic materials pave the way for students to experience the language learning.

Authentic materials can still be useful in another way; empirical studies have confirmed that less proficient students can benefit from such materials. In an investigation of high school students studying German as a FL, Bernhardt and Berkemeyer (1988) found that all levels of students have the capacity to manage using authentic texts. Maxim (2002) concluded, "The students' limited linguistic competence did not short-circuit their ability to read authentic texts in class with the support of their classmates and instructor" (p.29)

The findings of the above-mentioned studies have indicated that authentic materials can be useful in many ways. Such materials introduce students to how language is used in the real world and improve their overall language proficiency as well as reading and listening comprehension, communicative competence, and lexical and stylistic knowledge. However, such advantages run counter to arguments that the use of authentic materials at early stages hinders the language learning process. Nevertheless, incorporating authentic materials in teaching a FL offers more than just linguistic advantages. In this regard, scholars maintain for the motivating power of authentic materials (Gilmore, 2007; Sherman, 2003), which by and large, is a key factor in successful language learning (Keiko Komiya, 1992; Krashen, 1981; Masgoret \& Gardner, 2003). As Gilmore (2007) states, "Claims that authentic materials are a motivating force for learners are widespread through the literature" (p. 106). Similarly, McNeil (1994) \& Kilickaya (2004) argue that since authentic texts donates the learner the feeling that he or she is learning the real language - the target language as it is used by social colonies that speak it their use is now regarded as one way for enhancing students' motivation for learning. Rivers (1987) asserts that students who work with authentic materials have a practical intention and dynamic interest in the language. Kim (2000) argues that authentic materials provide a means for learners to overcome certain cultural barriers to language learning. Sherman (2003) states, "One reason why [authentic material] is so important for language learning is that it is a window into culture" (p.12) Despite these, some scholars rarely see any worth for authentic materials. Clark (1983), claims that there is no effect learning via media under any conditions; thus, the question of authentic versus non-authentic makes no difference (as cited in Miller, 2005). Similarly Kienbaum et al. (1986) pointed out there is no significant differences in the language performance of children using authentic materials compared with those in a more traditional classroom context.

Authentic materials, says Martinez (2002), may be too culturally biased and difficult to understand outside the language community. Nostrand (1989) says: "Authentic texts from one culture may give a false impression to a student from another unless they are presented in an authentic context which makes it clear precisely what they exemplify" (p.49).

In sum, the idea of authenticity in language teaching has been debated over the past three decades. However, the benefits that authentic materials bring to the FL classroom may be said to greatly outweigh the difficulties they might give rise to. In other word there is a trade-off. In addition, it is possible to overcome such challenges

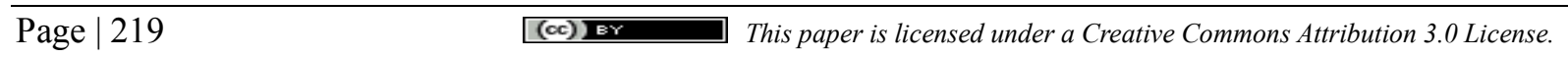


through task design. In Field (1998,as cited in Richards \& Renandya, 2002) "instead of simplifying the language of the text, simplify the task that is demanded of the student. ...With the text above the language level of the class, one demands only shallow comprehension" (p.244). Guariento and Morley (2001) also claimed that such difficulties can be overcome by designing tasks that require only partial comprehension. In conclusion, it is clear from the above review that incorporating authentic materials into the FL/SL classroom is worthwhile. To sum up here is positive effect of authentic listening materials reiterated in the review above. The main advantages of using authentic listening materials are (Philips \& Shettlesworth 1978; Clarke 1989; Peacock 1997, cited in Richards, 2001):

- They have a positive effect on learner motivation.

- They provide authentic cultural information and exposure to real language.

- They relate more closely to learners ' needs.

- They support a more creative approach to teaching.

\subsubsection{Selection of authentic materials}

According to Berardo (2006), there are three criteria for choosing authentic texts: suitability of content, exploitability, and readability. Suitability of content refers to the idea that the text should be in congruence with students 'needs and interests. For Bacon and Finneman (1990) the cultural relevance of the text to the experience of the students should be taken into account. Lee (1995) states that, "a careful and wise selection of materials focused on learners is a must if we want a positive response from them" (p.325). Moreover, exploitability refers to usability of the texts for developing the students' competence and its exploitability for teaching purposes. Finally, readability refers to the language of the text, including the structural and lexical difficulty as well as the amount of new vocabulary and grammatical forms. Brown \& Eskenzai (2004) say that the primary criteria for selecting appropriate authentic text should be the reader's current vocabulary knowledge and the desired vocabulary knowledge throughout the curriculum, in addition to grammar difficulty and text cohesiveness. However, Rivers (1987) claims that the primary criterion for selecting appropriate authentic text is content. He states, "although length, linguistic complexity, and interest for the student all play significant roles in the selection of materials, the single most important criterion for selection is content" (p. 50). Meanwhile, Rivas (1999) and Mishan (2005) argue that learners' interests and needs are the most essential factors in the choice of authentic texts. Little et al (1989, p 71), state that "The more texts are related to learners' personal concerns and interests the deeper and more rabid the processing will be" (as cited in Mishan, 2005, p.28). Moreover, Lee (1995) states that the text must be in harmonious with the course objectives, i.e. it can improve the language skills educators want the learners to practice. Besides, both the length of the text and teaching approach must be considered by the teachers. Further, a variety of genres must be selected, such as articles, advertisements, interviews, poems, application forms, train timetables, and brochures.

\subsubsection{A review on the research on realm of authentic listening texts (materials) on teaching}

A study done by _Lingzhu \& Yuanyuan(2010) under the title of "the use of authentic materials in teaching EFL listening" revealed that using authentic materials is an non-negotiable item and in dealing with that encountering some problem is inevitable. For its probable challenges being "too culturally based" containing "difficult language, unneeded vocabulary items and complex language structures (Richard, 2001). So students should equipped sufficient cultural background knowledge and vocabulary and grammar knowledge. They also mentioned that authentic materials can be problematic for the teachers too. Therefore, they claimed, special preparation is necessary for them. Moreover, they added that although authentic listening materials are most for advanced learners but using authentic materials should not be dismissed for early levels. They reflected their conclusion to Field (2008) that limiting listeners to graded materials, fitted with their levels, disqualify them in the outside face to face wrestling with the language. They pointed out to the ways for introducing authentic (listening) materials to elementary students. This ways, of course, reiterated in the literature by scholars, (Field.2008, Anderson \& Lynch, 1988).

1. Simplifying the task: as teachers may counter-balance the increased linguistic difficulty of the text by simplifying the requirements of the task (Anderson and Lynch, 1988). It is not necessarily the language that makes a piece of listening difficult. Difficulty may also arise from the task that is set. It is possible to use a listening passage which is well beyond the learners' level, provided that what is demanded of the learner is correspondingly simple. If one notches up the text, one notches down the task. (Field: 2008) 
2. Grading the text: it is important to bear this point in mind that even in the authentic materials the types, mood, and genres of texts is not the same for learners in terms of difficulty, so having different sample is important finally bearing following points into account is important while grading (Field 2008, cited in Lingzhu \& Yuanyuan (2010))

- More frequent vocabulary;

- Simple syntax;

- Simpler and less dense ideas and facts;

- A degree of redundancy, with ideas/facts expressed more than once;

- A degree of repetition, with the same form of words repeated;

- A very specific context or genre of communication which to some extent pre-determines how participants behave; (Field:2008)

Peacock (2000) did a study under the title of "The effect of authentic materials on the motivation of EFL learners" project to investigate whether authentic materials increase the classroom motivation of learners, to test a hardly ever claim. He selected two beginner-level EFL classes as a participation, used authentic and artificial materials alternately. Results from two observation sheets and a self-report questionnaire revealed that while on-task behavior and observed motivation increased significantly when authentic materials were used. However, authentic materials were significantly less interesting than artificial materials for them.

Madden (2008) in his study follow a series of techniques for adapting authentic listening and proposed a sort of continues dealing with materials from media and its repetition in oral mood. Chavez (1998) did survey asking 190 university-level learners of German to rate 53 situations (composed of 12 authenticity factors) on their level of (a.) authenticity; (b.) contribution to language learning; (c.) ease/difficulty; and (d.) resulting anxiety/enjoyment. Results showed that learners view authentic materials as essential to language learning and enjoyable. In contrast, positive correlations between authenticity and perceived difficulty were rare. He found, learners enjoy interacting with authentic materials but are appreciative of pedagogical support, especially in listening situations and when reading literary texts. In short, he found that learners prefer grading tasks to grading texts. Rebecca Noelle Norris (2011) in his thesis on authentic video and audio for developing cultural awareness in listening explored the positive aspects of combining the visual and auditory modes to present authentic samples of contextualized language and culture through video. He notably made authentic listening materials more tuning for beginner by combining tasks. As he concluded accompanying tasks provide authentic means for beginning English Language Learners to gain exposure to, and learn to use, the English language as it is spoken by native-speakers in the local setting. He found that the videos, materials, and tasks also highlight varied cultural themes and can be used supplementary.

The number of researches in the realm of authentic materials in Iran is not so many. A thesis under the title of "a study of the problem of authenticity and comprehensibility of linguistic input in second language acquisition" done at Tabriz University, by Nowrouzi (1997). This study concentrated on the issues of comprehensibility of linguistic input and its authenticity in second or foreign language acquisition. If the learners are exposed to adapted, simplified texts, though comprehensible as a essential for acquisition, but might be bereft of naturalness and loses its authenticity .from the other hand, exposing learners to original authentic texts , might be difficult, if not impossible, for learners to grasp very, if any. In his study, he discussed a controversial but covered issue regarding the dilemma how to compromise between simplified materials and authentic ones for arriving at appropriate outcome regarding learning. Having discussed the nature of each, he came up with some solutions in doing so. He recommended that the presentation of materials should be as authentic-like as possible. In addition, the activities should be simplified via instruction.

In another study (thesis) conducted by Keshavarz Hedayati (1999) under the title of "the effect of authentic broadcast materials on the listening comprehension of Iranian EFL Learners". This study carried out in the time of study at university level so as to achieve the purpose of the study of the probable significance of authentic materials over simplified materials and it effect on learners' motivation. Having selected two groups of both male and female in each, they assigned to control and experimental group randomly. As it was claimed in the study, seemingly they passed their intermediate courses. Having been fed with authentic broadcast and simplified materials, experimental and control groups each received a different treatment respectively. The experimental group was also received necessary background knowledge. After 13 sessions of teaching for either 
International Journal of Applied Linguistics \& English Literature

ISSN 2200-3592 (Print), ISSN 2200-3452 (Online)

Vol. 1 No. 4; September 2012

the similar test administered. Having analyzed the data taken he concluded that using authentic materials have a significant on students' comprehension and their motivation improved.

\subsection{Research questions}

The following questions will derive the present study.

1) Does listening to authentic materials make a significant difference between the experimental and control regarding the listening skill?

2) What is the attitude of students' toward authentic listening materials?

Based on the research question (question number 1) above and the nature of the study the null hypotheses are as follow:

\section{First hypothesis (H0)1: there is no relationship between using authentic listening materials and students' listening skills.}

Second hypothesis (H0)2: there is no correlation between students' attitudes authentic listening materials regarding and using authentic listening materials

\section{Method of study}

\subsection{Participants}

The study was carried out in Koshyar non-profit university located in Golsar district, Rasht, Guilan, Iran. Sixty students participated in the study. Because of the level, they were checked by Oxford placement test so as to be unanimously elementary. After that they were assigned to two equal groups randomly. One group labeled as a control group, receiving simplified (graded) listening materials and the other labeled as experimental group received authentic listening materials. There were two main reasons for selecting control group: the first reason refers back to idea that the dominant materials for teaching listening are graded (simplified) materials. Second was, these materials are plentifully worked in foreign language teaching. The students were all in their courses conducting English for general purpose, aged from 18 to 27. They were majoring in non-English majors, such as computer software, business management, accounting, etc. their proficiency level was elementary. Nearly the participants had not taken any English class so their speaking was so poor. Their mother tongue was Persian.

\subsection{Materials}

To determine the comparative effectiveness of authentic or simplified materials, two series of materials from either were selected. Authentic materials as was defined above are those which are produced by native speaker or materials in which produced for non-pedagogical purposes. Simplified or graded are those materials which produced for teaching. As many argued, we believed that listening is an unjustly-neglected skill in foreign language teaching. As Nunan (1990) asserted, listening is a Cinderella skill. We select a series of video and audio tracks. Due to the definition we brought at the outset, it was a bit difficult to find materials which serve two features native-speakers produced and for the purpose of other than language teaching. The rationale for the selection of these genres, were the fact that, it fulfills two conditions cited in the definition of authentic materials. First it is produced by native speakers and enjoys non-teaching -oriented purposes. The foremost reason was that they included the natural adaptability to the level. These were a series of audio material about wildlife, urban perspective, treating with nature and so forth.

\subsection{Instruments}

The instruments in this study were an English level test (Oxford Placement Test), a pre-test, a post-test and a student feedback survey: the English level test (OPT) (see the appendix I) was a paper-based test administered to check their levels. The English proficiency test for listening is further used for comparison of two kinds of materials. This test used both as pre-test and post- test; each includes two series of test. This test had two parts; the first part was based on the recognition type test so as to test students' perception. This test consisted of 100 two-choice questions. According to the manual of this test each question enjoyed two credits, in other words the score of the test was out of 200. According to what was mentioned in the definition, perception is one of the sub-skills of listening. Due to that we took it as the instrument for the purpose of comparison. By the same token, a 30-multiple-choice comprehension test was taken for the comparison of listening comprehension as another sub-skill of listening skills as defined in the section of 2.6.2. Similarly it goes without saying that according to the test manual each question enjoys one credit the validity and reliability of the tests also has been warranted. To sum up there are three reasons for selecting these tests: 
International Journal of Applied Linguistics \& English Literature

ISSN 2200-3592 (Print), ISSN 2200-3452 (Online)

Vol. 1 No. 4; September 2012

1)They are valid and reliable tests and are administered to a large population internationally.

2)They are manageable, easily-scored, justifiable tests.

The post-test was the same as the pre-test. In other words the pre and post test were similar in content and domain. Finally, the students had a chance to provide feedback as far as the materials they were exposed. The instructor administered a student feedback survey (adapted from Enas Ibrahim Al-Musallam 2009) which asked a series questions to generate the students' opinions and perspectives on instructional materials, i.e. authentic listening materials. The survey asked how effective the students found the authentic materials, and how prepared they felt following instruction. It was a likert -based scale questionnaire. Results of the survey provided valuable information that helped to explain the conclusions of the study provided by the analysis of the data collected.

\section{Results}

The results were depicted in following tables.

Table.1. Paired sample statistics of CG and EG in pretest and post test (LCT)

\begin{tabular}{rrrrrl}
\hline & & Mean & $\mathrm{N}$ & Std. Deviation & Std. Error Mean \\
\hline Pair 1 & $\begin{array}{r}\text { Pretest } \\
\text { LCT }\end{array}$ & 8.00 & 60 & 4.034 & .521 \\
& $\begin{array}{r}\text { Posttest } \\
\text { LCT }\end{array}$ & 17.62 & 60 & 4.346 & .561 \\
\hline
\end{tabular}

Table 2. Paired Samples Test for the comparison of EG\&CG in pretest and post test(LCT)

\begin{tabular}{|c|c|c|c|c|c|c|c|c|c|}
\hline & & \multirow{3}{*}{ Mean } & \multirow{3}{*}{$\begin{array}{r}\text { Std. } \\
\text { Deviation }\end{array}$} & \multicolumn{3}{|c|}{ Paired Differences } & \multirow[t]{3}{*}{$\mathrm{t}$} & \multirow{3}{*}{$\mathrm{df}$} & \multirow{3}{*}{$\begin{array}{r}\text { Sig. } \\
\text { (2-tailed) }\end{array}$} \\
\hline & & & & $\begin{array}{l}\text { Std. } \\
\text { Error }\end{array}$ & $\begin{array}{r}95 \% \text { Confidence } \\
\text { of the Di }\end{array}$ & $\begin{array}{l}\text { Interval } \\
\text { ifference }\end{array}$ & & & \\
\hline & & & & Mean & Lower & Upper & & & \\
\hline $\begin{array}{ll}\text { Pair } 1 & \begin{array}{l}\text { Pretest } \\
\text { Posttest }\end{array}\end{array}$ & $\begin{array}{l}\text { LCT } \\
\text { LCT }\end{array}$ & 9.617 & 4.712 & .608 & -10.834 & -8.399 & -15.807 & 59 & .000 \\
\hline
\end{tabular}

As the tables show, the mean of pretest scores is 8 and the mean of posttest scores is 17.62 . Since the level of significance is considered 0.05 , therefore it can be concluded that the difference between two groups is significant and the instruction plays a great role. It can be concluded that students whom exposed to authentic listening materials performed better than those students whom introduced to simplified (graded) listening materials. These differences also tell that exposing to authentic listening materials makes students more proficient in listening comprehension.

Table 3. Paired Samples Statistics CG \&EG in LPT

\begin{tabular}{|c|c|c|c|c|c|}
\hline & & Mean & $\mathrm{N}$ & Std. Deviation & Std. Error Mean \\
\hline \multirow{2}{*}{ Pair 1} & Pr LPT & 106.48 & 60 & 25.516 & 3.294 \\
\hline & Po LPT & 135.50 & 60 & 26.544 & 3.427 \\
\hline
\end{tabular}

Table 4. Paired Samples Test of CG \&EG in LPT

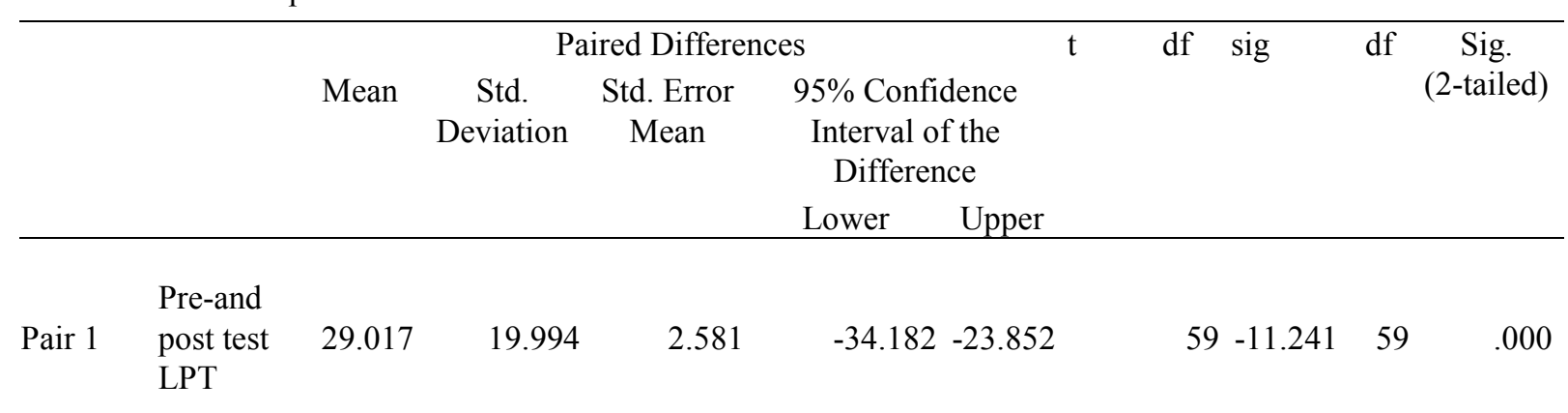




\section{International Journal of Applied Linguistics \& English Literature}

ISSN 2200-3592 (Print), ISSN 2200-3452 (Online)

Vol. 1 No. 4; September 2012

As the tables illustrate, the mean of pretest scores is 106.48 and the mean of posttest scores is 135.50. Since the level of significance is considered 0.05 , therefore it can be concluded that the difference between two groups is significant and the instruction plays a great role.

Besides empirical data which was collected, and the statistical analyses which were conducted in the current study, the opinions from the participants of the study also provided valuable insights regarding the effectiveness of authentic listening materials. A survey concerning to the students' perception, with regard the authentic listening materials administered to each student exposing to treatment. This feedback survey was adapted from E. I. Al-Musallam(2009). Before conducting the study it was culturally adapted and statically tested to warrant test reliability $(\mathrm{r}=0.61)$.

The survey contained 35 multiple-choice questions. (See appendix). Having compared the answers of multiple-choice, it was revealed that the experimental group receiving treatment responded much more favorably on the majority of the questions, exerting a higher level of satisfaction with the authentic listening materials. The result of percentages of analysis explicates that the experimental group who received treatment scored high in the most of the variables such as willingness and preference to use authentic materials, tendency to listening to authentic listening materials, usability of authentic listening materials in social and out of class situation, motivational power of authentic listening materials, the effect of authentic listening materials on speaking, grammar ,vocabulary proficiency and the effectively of authentic listening materials on listening skills. Moreover movie and music was the most significant sources of authentic listening materials for them. Besides TV and movie were the most accessible sources for student. The result of this survey confirmed that:

Iranian Elementary students (university level) have positive attitudes toward using authentic listening materials.

Table 5. Experimental group reaction to the multiple-choice questions of survey

\begin{tabular}{|c|c|c|c|c|}
\hline \multirow{2}{*}{$\begin{array}{l}\text { 1- I prefer to use } \\
\text { English authentic } \\
\text { materials rather than } \\
\text { listen to those } \\
\text { provided in the } \\
\text { course book. }\end{array}$} & Strongly Agree & Agree & Disagree & Strongly Disagree \\
\hline & $26.8 \%$ & $22.0 \%$ & $39.0 \%$ & $12.2 \%$ \\
\hline \multirow{2}{*}{$\begin{array}{l}\text { 2. I prefer to use } \\
\text { simplified listening } \\
\text { materials provided } \\
\text { in the course book }\end{array}$} & Strongly Agree & Agree & Disagree & Strongly Disagree \\
\hline & $5.0 \%$ & $25.0 \%$ & $60.0 \%$ & $10.0 \%$ \\
\hline \multirow{2}{*}{$\begin{array}{l}\text { 3. I prefer to use a } \\
\text { combination of } \\
\text { English authentic } \\
\text { materials. }\end{array}$} & Strongly Agree & Agree & Disagree & Strongly Disagree \\
\hline & $45 \%$ & $30 \%$ & $15 \%$ & $10 \%$ \\
\hline \multirow{2}{*}{$\begin{array}{l}\text { 4. I prefer not to use } \\
\text { simplified listening } \\
\text { materials provided } \\
\text { in the course book }\end{array}$} & Strongly Agree & Agree & Disagree & Strongly Disagree \\
\hline & $41 \%$ & $29 \%$ & $10 \%$ & $20 \%$ \\
\hline \multirow{2}{*}{$\begin{array}{l}\text { 5. I prefer not to use } \\
\text { authentic listening } \\
\text { materials }\end{array}$} & Strongly Agree & Agree & Disagree & Strongly Disagree \\
\hline & $14.6 \%$ & $36.6 \%$ & $43.3 \%$ & $4.9 \%$ \\
\hline \multirow{2}{*}{$\begin{array}{l}\text { 6. I prefer not to use } \\
\text { a combination of } \\
\text { English authentic } \\
\text { materials }\end{array}$} & Strongly Agree & Agree & Disagree & Strongly Disagree \\
\hline & $2.4 \%$ & $51.2 \%$ & $41.5 \%$ & $4.9 \%$ \\
\hline \multirow{2}{*}{$\begin{array}{l}\text { 7. Listening } \\
\text { materials I usually } \\
\text { do not listening } \\
\text { English unless I } \\
\text { have to }\end{array}$} & Strongly Agree & Agree & Disagree & Strongly Disagree \\
\hline & $7.5 \%$ & $75 \%$ & $12.5 \%$ & $5 \%$ \\
\hline
\end{tabular}


International Journal of Applied Linguistics \& English Literature

ISSN 2200-3592 (Print), ISSN 2200-3452 (Online)

Vol. 1 No. 4; September 2012

\begin{tabular}{|c|c|c|c|c|}
\hline \multirow{2}{*}{$\begin{array}{l}\text { 8. Authentic } \\
\text { listening materials } \\
\text { help me improve my } \\
\text { language } \\
\text { proficiency }\end{array}$} & Strongly Agree & Agree & Disagree & Strongly Disagree \\
\hline & $34.1 \%$ & $48.8 \%$ & $2.4 \%$ & $14.6 \%$ \\
\hline \multirow{2}{*}{$\begin{array}{l}\text { 9. The authentic } \\
\text { materials I listened } \\
\text { in class are easier } \\
\text { than non-authentic } \\
\text { materials }\end{array}$} & Strongly Agree & Agree & Disagree & Strongly Disagree \\
\hline & $10.5 \%$ & $30.5 \%$ & $35 \%$ & $24 \%$ \\
\hline \multirow{2}{*}{$\begin{array}{l}10 . \text { The authentic } \\
\text { materials I listened } \\
\text { in class are more } \\
\text { interesting than } \\
\text { non-authentic } \\
\text { materials. }\end{array}$} & Strongly Agree & Agree & Disagree & Strongly Disagree \\
\hline & $48.8 \%$ & $39.1 \%$ & $4.9 \%$ & $12.2 \%$ \\
\hline \multirow{2}{*}{$\begin{array}{l}\text { 11. Authentic } \\
\text { listening materials } \\
\text { enable me to } \\
\text { comprehend other } \\
\text { materials outside the } \\
\text { class. }\end{array}$} & Strongly Agree & Agree & Disagree & Strongly Disagree \\
\hline & $41 \%$ & $25.5 \%$ & $25.6 \%$ & $7.7 \%$ \\
\hline \multirow{2}{*}{$\begin{array}{l}\text { 12. Authentic } \\
\text { listening materials } \\
\text { the listening course } \\
\text { motivates me to } \\
\text { listen other } \\
\text { materials outside the } \\
\text { class }\end{array}$} & Strongly Agree & Agree & Disagree & Strongly Disagree \\
\hline & $40 \%$ & $25 \%$ & $20 \%$ & $15 \%$ \\
\hline \multirow{2}{*}{$\begin{array}{l}\text { 13. The listening } \\
\text { course introduces } \\
\text { me to how language } \\
\text { is used in the real } \\
\text { world }\end{array}$} & Strongly Agree & Agree & Disagree & Strongly Disagree \\
\hline & $35 \%$ & $30 \%$ & $20 \%$ & $25 \%$ \\
\hline \multirow{2}{*}{$\begin{array}{l}\text { 14. Authentic } \\
\text { listening materials } \\
\text { introduce me to how } \\
\text { language is used in } \\
\text { the real world }\end{array}$} & Strongly Agree & Agree & Disagree & Strongly Disagree \\
\hline & $50 \%$ & $20 \%$ & $12 \%$ & $8 \%$ \\
\hline \multirow{2}{*}{$\begin{array}{l}\text { 15. Authentic } \\
\text { listening materials } \\
\text { improve my } \\
\text { language } \\
\text { proficiency more } \\
\text { than those ones }\end{array}$} & Strongly Agree & Agree & Disagree & Strongly Disagree \\
\hline & $52 \%$ & $28 \%$ & $10 \%$ & $10 \%$ \\
\hline \multirow{2}{*}{$\begin{array}{l}\text { 16. Authentic } \\
\text { listening materials } \\
\text { improve my } \\
\text { listening } \\
\text { comprehension } \\
\text { ability more than } \\
\text { non-authentic }\end{array}$} & Strongly Agree & Agree & Disagree & Strongly Disagree \\
\hline & $35 \%$ & $24 \%$ & $26 \%$ & $15 \%$ \\
\hline
\end{tabular}

Page | 225 
International Journal of Applied Linguistics \& English Literature

ISSN 2200-3592 (Print), ISSN 2200-3452 (Online)

Vol. 1 No. 4; September 2012

\begin{tabular}{|c|c|c|c|c|}
\hline \multirow{2}{*}{$\begin{array}{l}\text { 17. Authentic } \\
\text { listening materials } \\
\text { Help develop my } \\
\text { speaking ability } \\
\text { more than } \\
\text { non-authentic do }\end{array}$} & Strongly Agree & Agree & Disagree & Strongly Disagree \\
\hline & $37 \%$ & $22 \%$ & $23.6 \%$ & $17.4 \%$ \\
\hline \multirow[b]{2}{*}{$\begin{array}{l}\text { 18. Authentic } \\
\text { listening materials } \\
\text { increase my } \\
\text { familiarity with the } \\
\text { use of grammar } \\
\text { rules in their } \\
\text { original context. }\end{array}$} & Strongly Agree & Agree & Disagree & Strongly Disagree \\
\hline & $34 \%$ & $26 \%$ & $18 \%$ & $22 \%$ \\
\hline \multirow[b]{2}{*}{$\begin{array}{l}\text { 19. Authentic } \\
\text { listening materials } \\
\text { increase my } \\
\text { knowledge of } \\
\text { vocabulary items } \\
\text { which I need in real } \\
\text { situations }\end{array}$} & Strongly Agree & Agree & Disagree & Strongly Disagree \\
\hline & $55 \%$ & $23 \%$ & $12 \%$ & $10 \%$ \\
\hline \multirow{2}{*}{$\begin{array}{l}\text { 20. Authentic } \\
\text { listening materials } \\
\text { are difficult for me } \\
\text { to comprehend. }\end{array}$} & Strongly Agree & Agree & Disagree & Strongly Disagree \\
\hline & $30 \%$ & $15 \%$ & $28 \%$ & $26 \%$ \\
\hline \multirow{2}{*}{$\begin{array}{l}\text { 22. Authentic } \\
\text { listening materials } \\
\text { motivate me to do } \\
\text { more listening } \\
\text { outside the } \\
\text { classroom }\end{array}$} & Strongly Agree & Agree & Disagree & Strongly Disagree \\
\hline & $57 \%$ & $23 \%$ & $12.2 \%$ & $8.8 \%$ \\
\hline \multirow[t]{2}{*}{ 23. TV commercials } & Strongly Agree & Agree & Disagree & Strongly Disagree \\
\hline & $22.4 \%$ & $4.2 \%$ & $49.2 \%$ & $24.4 \%$ \\
\hline \multirow[t]{2}{*}{ 24. Cartoons } & Strongly Agree & Agree & Disagree & Strongly Disagree \\
\hline & $31.7 \%$ & $12.2 \%$ & $7.3 \%$ & $48.8 \%$ \\
\hline \multirow[t]{2}{*}{ 25. News clips } & Strongly Agree & Agree & Disagree & Strongly Disagree \\
\hline & $45 \%$ & $33 \%$ & $12 \%$ & $10 \%$ \\
\hline \multirow[t]{2}{*}{ 26. Movies } & Strongly Agree & Agree & Disagree & Strongly Disagree \\
\hline & $56.6 \%$ & $26.4 \%$ & $8.2 \%$ & $12.8 \%$ \\
\hline \multirow{2}{*}{$\begin{array}{l}\text { 27. taped short } \\
\text { stories and novels }\end{array}$} & Strongly Agree & Agree & Disagree & Strongly Disagree \\
\hline & $34 \%$ & $14 \%$ & $46 \%$ & $6 \%$ \\
\hline \multirow[t]{2}{*}{ 28. Radio ads } & Strongly Agree & Agree & Disagree & Strongly Disagree \\
\hline & $44 \%$ & $23 \%$ & $14 \%$ & $16 \%$ \\
\hline
\end{tabular}


International Journal of Applied Linguistics \& English Literature

ISSN 2200-3592 (Print), ISSN 2200-3452 (Online)

Vol. 1 No. 4; September 2012

\begin{tabular}{|c|c|c|c|c|c|}
\hline \multirow[t]{2}{*}{ 29. Music } & \multicolumn{2}{|c|}{ Strongly Agree } & Agree & Disagree & Strongly Disagree \\
\hline & \multicolumn{2}{|c|}{$50 \%$} & $27 \%$ & $21 \%$ & $2 \%$ \\
\hline \multirow{5}{*}{$\begin{array}{l}30 . \text { What medium } \\
\text { do you use most } \\
\text { often to obtain } \\
\text { authentic listening } \\
\text { material? }\end{array}$} & \multicolumn{2}{|c|}{ Strongly Agree } & Agree & Disagree & Strongly Disagree \\
\hline & TV & $40 \%$ & $30 \%$ & $20 \%$ & $10 \%$ \\
\hline & Radio & $29 \%$ & $11 \%$ & $29 \%$ & $29 \%$ \\
\hline & Films & $59 \%$ & $18 \%$ & $19 \%$ & $3 \%$ \\
\hline & internet & $45 \%$ & $25 \%$ & $25 \%$ & $5 \%$ \\
\hline
\end{tabular}

\section{Discussions}

We can conclude that, experimental group, the group who received authentic listening materials performed much better than control group who received simplified listening materials. The results showed students receiving authentic listening materials got better score in listening perception test justified via statistical analyses. These conclusions demonstrated and elaborated the efficiency of authentic listening materials in developing listening perception as an important component of listening skills.

To sum up, comparing and contrasting the statistical results taken from the study justified and confirmed the hypothesis:

H0)1: there is positive relationship between using authentic listening materials and students' listening skills.

Exposing to Authentic listening materials has a positive effect on listening skills of students at the elementary level.

As it was observed, authentic listening materials are more effective than simplified listening materials at elementary level, provided that they are instructed in logical manner as it was reiterated in the literature (Lingzhu \& Yuanyuan, 2010; Field, 2008; Anderson \& Lynch, 1988). As they reflected limiting listeners to graded materials, fitted with their levels, lead to their disqualification from the outside exposure to real language e -face to face -wrestling with the language. As they pointed out task simplification, and text gradation and staging the listening progression should be taken into account while introducing authentic (listening) materials to elementary students. To sum up, based on the qualitative and quantitative analysis of the preliminary proficiency test, a listening comprehension, and a listening perception test, and also students' feedback survey several findings were revealed. The proficiency test at outset of study revealed that both groups at the same level of proficiency, in fact, both groups were homogenous. The patterns observed in the results of the study explicated that the authentic listening materials had a positive effect on listening skills of elementary students at university level. By listening skills it meant listening perception and listening comprehension at the beginning of study. Put simply, experimental group performed better than control group in both tests of listening perception and listening comprehension.

\section{Suggestions for further researches}

The conclusion of this study maintains the need for further study into the impact of authentic listening materials in developing listening skills.

Due to favorable impact of authentic listening materials, there is a need to investigate the effectiveness of different genres and modes of authentic listening materials. It also worth recommending that, the impact of different modes and genres of authentic materials investigate at elementary level.

Next, the study can be wider in scope if it includes all possible modes and sources of authentic materials such audios, videos, from different sources, it also enjoys more pedagogical significance if compares contrasts these discrepancies and their efficiencies in developing listening skills.

Also the impact of authentic listening materials can be investigated to see its effect on other aspect of language acquisitions such learning and intonation, stress patterns, vocabulary proficiency, incidental learning, extra linguistic factors, grammar, establishing speaking and so forth. 
Different listening strategies in relation to authentic listening materials and non-authentic materials (simplified) in different levels of proficiency can be a fruitful study as well.

Finally the impact of authentic listening materials on listening skills (barring the two targeted in this study; listening perception and listening comprehension) at elementary and other levels will be valuable study as well.

\section{References}

Adams, T. (1995). What Makes Materials Authentic? (ERIC Document Reproduction .Service No. ED 391389). Allen, J., \& Widdowson, H. G. (1979). Teaching the communicative use of English. In C.

Al-Musallam, E. I. (2009). College Instructors' and Learners' Attitudes to Authentic EFL Reading Materials in Saudi Arabia, unpublished thesis.

Allwright, R. (1981). language learning through communication practice. In C.J.Brumfit and K.Johnson(eds),the communicative approach to language teaching. Oxford university press. 167

Anderson, J. R.(1985).Cognitive Psychology and its implications(2nd ed) NewYork:W,H,Freeman.

Bacon, S M., and Finneman, M.D (1990). A study of the attitudes, motives, and strategies of university foreign language students and their disposition to authentic oral and written input. The Modern Language Journal, 74(4), 459-473

Berardo, S (2006). The use of authentic materials in the teaching of reading. The Reading Matrix, 6 (2), 60-69

Berne,J.E.(1998). Examining the relationship between L2 Listening pedagogical theory and practice

Breen, M.P. (1985). Authenticity in the language classroom. Applied Linguistics, 6(1), 60-70.

Brown, J., \& Eskenazi, M. (2004).Retrieval of authentic documents for reader-specific lexical practice. In Proceedings of InSTIL/ICALL Symposium, Venice, Italy.

Chavez, M. (1998). Learner's perspectives on authenticity. IRAL, 36(4), 277-306.

Clarke, D. F , ( 1983) 'Materials adaptation: why leave it all to the teacher?' ELT Journal 43/2: 133-41.

Clarke, D. (1990), Communicative theory and its influence on materials production. Language Teaching 25/1, pp73-86

Darian, S. (2001). Adapting authentic materials for language teaching. English Teaching Forum, 39(2).

Ellis, R. (1994). The study of second language acquisition. Oxford: Oxford University Press.

Gilmore, A. (2004). A comparison of textbook and authentic interactions. ELT Journal, 58(4), 363-374.

Guariento, W. and Morley, J. (2001). Text and task authenticity in the EFL classroom. ELT Journal, 55(4), 347-353

Hadley, A. (2001). Teaching language in context (3rd edition). Boston: Thomson Heinle. Harmer.J (2007) the practice of English Language Teaching. $4^{\text {th }}$ ed, Rahnama publication.

Herron, C., \& Seay, I. (1991). The effect of authentic oral texts on student listening comprehension in the foreign language classroom. Foreign Language Annals, 24(6), 487-495.

Kilickaya. F. (2004). Authentic materials and cultural content in EFL classrooms. The Internet TESL Journal, 10 (7). Retrieved November 1, 2006 from http://iteslj.org/Techniques/Kilickaya-AutenticMaterial.html

Kim, D. (2000). A qualitative approach to the authenticity in the foreign language classroom: 'study of university students learning English in Korea. Texas Papers in Foreign Language Education, 5 (1), 189-205

Krashen. S.D. (1989). Principles and practice in second language acquisition .UK. Prentice hall international Kumaravadivelu , B. (2006). Understanding language teaching, from method to post method.

Larsen-Freeman, D. \& Long, M. (1991). An introduction to second language acquisition research. England: Longman

Lee, W.Y. (1995). Authenticity revisited: text authenticity and learner authenticity. ELT Journal, 49(4), 323-328

Madden.J. P. (2008). Helping ESL Students Adapt to Authentic Listening Situation, St. Cloud State University

(St. Cloud, MN. USA) jpmadden \{at\} stcloudstate.edu

Martinez, A. (2002). Authentic materials: An overview. Karen's Linguistic Issues.

Retrieved October 25, 2006 from http://www3.telus.net/linguisticsissues/authenticmaterials.html

McNeill, A. (1994). What Makes Authentic Materials Different? The Case of English Language Materials for Educational Television. Papers presented at the Annual International Language in Education.

Miller, M. (2005). Improving aural comprehension skills in EFL, using authentic materials: aexperiment with university students in Nigata, Japan. Unpublished master's thesis, University of Surrey, Australia. Conference, Hong Kong.

Mishan, F. (2005). Designing authenticity into language learning materials. Bristol: Intelect Ltd. 
International Journal of Applied Linguistics \& English Literature

ISSN 2200-3592 (Print), ISSN 2200-3452 (Online)

Vol. 1 No. 4; September 2012

Morley, J. (2001). Aural comprehension instruction. Principles \& practices, in M. Cele -Murcia(ed) teaching English as L2 or Foreign language $\left(3^{\text {rd }}\right.$ ed).U.S.A .

Morton, R. (1999). Abstracts as authentic material for EAP classes. ELT Journal, 53(3), 177-182.

Norris. N. N.(2011), Using Authentic Videos to enhance language and cultural instruction in formal English language learning setting:ten videos and accompanying lessons, UMI 1496825 Copyright 2011 by ProQuest LLC

Nunan, D. (1989). Designing Tasks for the Communicative Classroom. Cambridge: Cambridge University Press. Nunan, D. (1999).second language teaching and learning, Heinle \& Heinle publishers

Oxford, R. (1993). Research Update on L2 Listening. System 21:205-11. Richards, J, C. (2001)

Curriculum development in language teaching. Cambridge university press.

Peacock, M. (1997). The effect of authentic materials on the motivation of EFL learners. ELT

Journal, 51(2), 144-156.

Pearson, P.D. (1983). Instructional Implications of Listening Comprehension Research.

Richards, J. (1983). Listening Comprehension: Approach, Design, Procedure. TESOL Quarterly 17/2 pp.

219-239

Richards, J.C., \& Renandya, W.A. (2002). Methodology in language teaching. Cambridge university press.

Ring, L. (1986). Authentic language and authentic conversational texts. Language Annals, 19(3), 203-208.

Rogers, C. V. (1988). Language with a purpose: using authentic materials in the foreign language classroom.

Foreign Language Annals, 21(5), 467-476.

Rivers,W.(1966).Listening comprehension ,modern language Journal.50.196 204

Rivers, W.M. (1981). Listening Comprehension: Appraoch Design, Procedure. TESOL Quartly, USA.

Rost, M. (2002) Teaching and Researching Listening. London, UK: Longman. Sanderson, P. (1999), Using

Newspapers in the Classroom. Cambridge: Cambridge University Press

Schmitt, N. (2002) an introduction to applied linguistics, Oxford University press.

Schulz, R. (1991). Second language acquisition theories and teaching practice: How do they fit? The Modern

Language Journal, 75, 17-26

Thanajaro, Metinee; Shrum, J. L.(2000). Using authentic materials to develop listening comprehension in

the English as a second language classroom, Virginia Polytechnic Institute and State University, ISBN

9780599651029,0599651024

Vandergrift, L. (1999). Facilitating second language listening comprehension: Acquiring Successful Strategies.

ELT Journal 53:168-76.

Widdowson, H.G. (1978). Explorations in applied linguistics, Oxford University press

Widdowson, H.G. (1996). Comment: authenticity and autonomy in ELT. ELT Journal, 50(1), 67-68. 